\title{
A typical case of scrub typhus (tsutsugamushi disease)
}

\author{
Sho Fujiwara, ${ }^{1}$ Taro Shimizu ${ }^{2}$
}

${ }^{1}$ Iwate Prefectural Chubu Hospital, Iwate, Japan ${ }^{2}$ Joto Hospital, Tokyo, Japan

\section{Correspondence to} Dr Taro Shimizu, shimizutaro7@gmail.com

Accepted 12 October 2014
To cite: Fujiwara $S$, Shimizu T. BMJ Case Rep Published online: [please include Day Month Year] doi:10.1136/bcr-2014207824

\section{DESCRIPTION}

A 79-year-old Japanese woman presented to the emergency department with a 4-day history of fever $\left(37-39^{\circ} \mathrm{C}\right)$ of unknown origin, headache and loss of appetite. She denied respiratory distress and other symptoms; her $\mathrm{SpO}_{2}$ was $88 \%$ on room air. Two weeks before presentation, she travelled to a mountain in Japan to collect edible plants.

On physical examination, purple-coloured, nonpruritic eruptions were observed on her face, extremities and trunk (figure 1). An eschar was observed in the left lower extremity (figure 2). Laboratory tests revealed the following: platelet count $70000 / \mu \mathrm{L}$; aspartate aminotransferase level $144 \mathrm{U} / \mathrm{L}$ and alanine aminotransferase level $444 \mathrm{U} / \mathrm{L}$. Serological tests revealed high Orientia tsutsugamushi IgG and IgM antibody titres. She was diagnosed with scrub typhus (tsutsugamushi disease) and was started on $200 \mathrm{mg}$ of minocycline. After 2 weeks of the treatment, her symptoms resolved and the eruptions disappeared. She was discharged without complication.

Scrub typhus, also known as tsutsugamushi disease, is an acute lethal infectious disease caused by O. tsutsugamushi. It is endemic to the Asian Pacific area. Common clinical manifestations of the disease are febrile, headache and rash. ${ }^{1}$ Diagnosis is difficult because many patients present as fever of unknown origin. Evidence of an eschar is the only

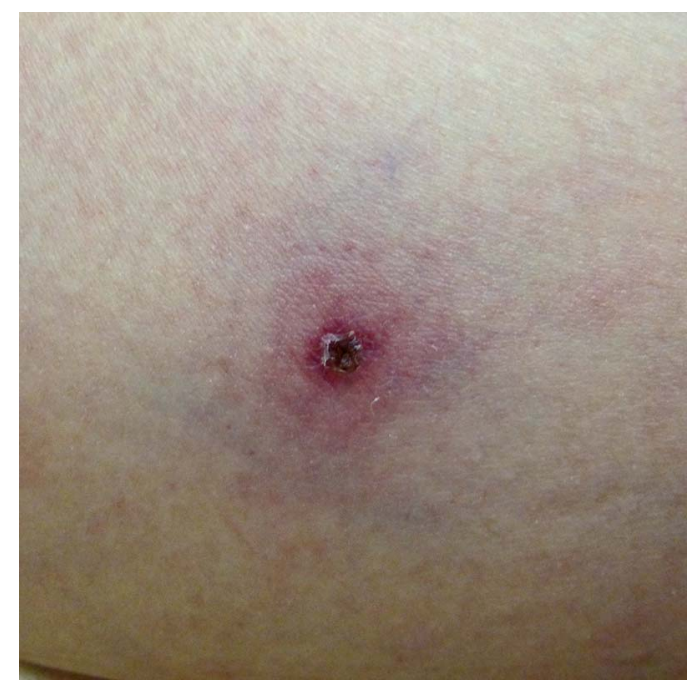

Figure 1 Purple-coloured, non-pruritic eruptions on the trunk.

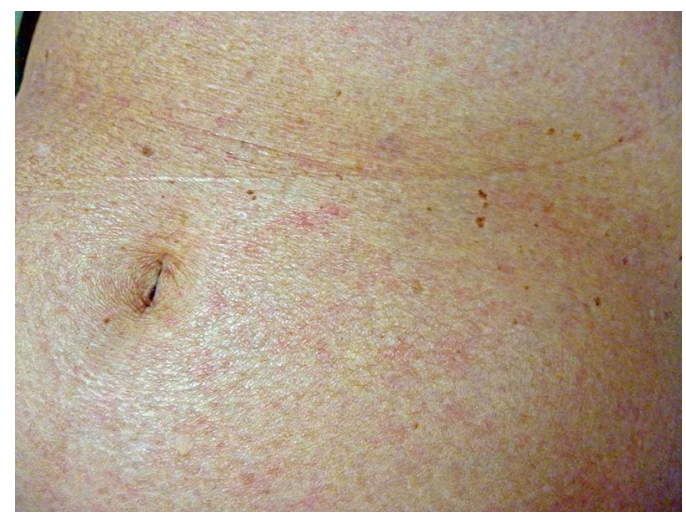

Figure 2 An eschar in the left lower extremity.

clue for the diagnosis, while serological methods play limited roles in making a decision on whether or not treatment should be initiated. ${ }^{2} 3$

\section{Learning points}

- Scrub typhus is a lethal infectious disease; it is difficult to diagnose without experience.

- Fever of unknown origin and low platelet count in a patient could be clues to diagnose the disease.

- A thorough inspection of the skin for an eschar, a pivotal indicator for scrub typhus diagnosis, is essential.

Contributors SF saw the patient and wrote the manuscript.

TS saw the patient and revised the manuscript.

Competing interests None.

Patient consent Obtained.

Provenance and peer review Not commissioned; externally pee reviewed.

\section{REFERENCES}

1 Kelly DJ, Fuerst PA, Ching W-M, et al. Scrub typhus: the geographic distribution of phenotypic and genotypic variants of Orientia tsutsugamushi. Clin Infect Dis 2009;48(Suppl 3):S203-30.

2 Kim D-M, Won KJ, Park CY, et al. Distribution of eschars on the body of scrub typhus patients: a prospective study. Am I Trop Med Hyg 2007;76:806-9.

3 Koh GCKW, Maude RJ, Paris DH, et al. Diagnosis of scrub typhus. Am J Trop Med Hyg 2010;82:368-70. 
Copyright 2014 BMJ Publishing Group. All rights reserved. For permission to reuse any of this content visit http://group.bmj.com/group/rights-licensing/permissions.

BMJ Case Report Fellows may re-use this article for personal use and teaching without any further permission.

Become a Fellow of BMJ Case Reports today and you can:

- Submit as many cases as you like

- Enjoy fast sympathetic peer review and rapid publication of accepted articles

- Access all the published articles

- Re-use any of the published material for personal use and teaching without further permission

For information on Institutional Fellowships contact consortiasales@bmjgroup.com

Visit casereports.bmj.com for more articles like this and to become a Fellow 